співіснуванні народної та академічної практики підготовки баяністів-акордеоністів у системі музичної освіти.

Перспективи подальших наукових розвідок убачаємо в подальшому дослідженні типів сербської баянно-акордеонної школи в контексті єдиної музично-освітньої національної системи зазначеної країни.

\title{
Література
}

1. Альшванг А. Людвиг ван Бетховен: очерк жизни и творчества / А. Альшванг. Москва : Музыка, 1966. - 630 с. 2. Варламов Д. Народное в музыкально-инструментальном искусстве / Д. Варламов. - Саратов : Издательский центр «Наука», 2007. - 164 с. 3. Соколов О. Морфологическая система музыки и еe художественные жанры / О. Соколов. - Нижний Новгород : Изд-во Нижегородского университета, 1994. - 215 с. 4. Сохор А. Эстетическая природа жанра в музыке / А. Сохор. - Москва : Музыка, 1968. 105 с. 5. Суббота О. В. Музична моторність як категорія музикознавства: дис. ... канд. мистецтвознавства: 17.00 .03 / О. В. Суббота. - Одеса, 2005. - 197 с. 6. Besseler Н. Spielfiguren in der Instrumentalmusik / Besseler H. Jahrbuch, Leipzig, 1956. - P. 13-58.

УДК 37.017.7:373.9

Світлана Федоренко

\section{НАВЧАЛЬНІ КУРСИ-СЕМІНАРИ ДЛЯ СТУДЕНТІВ ПЕРШОГО РОКУ НАВЧАННЯ В СИСТЕМІ ЗАГАЛЬНОЇ ГУМАНІТАРНОЇ ПІДГОТОВКИ У ВИЩІЙ ШКОЛІ США}

Федоренко С. В. Навчальні курси-семінари для студентів першого року начання в системі загальної гуманітарної підготовки у вищій школі США.

У статті висвітлено особливості навчальних курсів-семінарів у системі загальної гуманітарної підготовки у вищій школі США, які спрямовані на використання комунікації як ефективного інструментарію формування гуманітарної культури студентів. Розглянуто створення динамічної взаємодії між викладачами та студентами, де ідеї і знання передаються й обговорюються в критично-заохочувальній манері, що перетворює студентів на активних учасників власного навчання і виховання.

Ключові слова: гуманітарна культура студентів, комунікативні навички, вища освіта США, загальна гуманітарна підготовка, навчальні курси-семінари, студенти бакалавріату.

Федоренко С. В. Учебные курсы-семинары для студентов первого года обучения в системе общей гуманитарной подготовки в высшей школе США.

В статье освещены особенности учебных курсов-семинаров в системе общей гуманитарной подготовки в высшей школе США, направленные на использование коммуникации как эффективного инструментария формирования гуманитарной культуры студентов. Рассмотрено создание динамического взаимодействия между преподавателями и студентами, где идеи и знания передаются и обсуждаются в критически-поощрительной манере, превращая студентов в активных участников собственного обучения и воспитания.

Ключевые слова: гуманитарная культура студентов, коммуникативные навыки, высшее образование США, общая гуманитарная подготовка, учебные курсы-семинары, студенты бакалавриата.

Fedorenko S. V. Training seminars for the first year students in the system of general liberal education at the higher schools of the USA. 
The special features of training seminars for the first year students in the system of general liberal education at the higher schools of the USA are defined. They are aimed at using communication approach as an effective tool for liberal culture formation of students. The creation of dynamic interaction between instructors and students is considered. Under this approach the ideas are transmitted and discussed in a critical and rewarding way making students active participants of their own education.

Key words: students' liberal culture, skills of communication, higher education in the USA, general liberal training, training courses, undergraduate students.

Перший рік навчання у вищій школі є важливим тому, що в цей час відбувається значна кількість змін у розумовій та емоційній сферах студентів. Свідченням цього $є$ визнання численними американськими педагогами того, що досвід студентівпершокурсників бакалавріату охоплює інтелектуальну, соціальну, емоційну та культурну адаптацію, яка, у свою чергу, передбачає активну взаємодію студентів та освітнього середовища. При цьому саме викладачі відіграють важливу роль у процесах набуття зазначеного досвіду, створюючи сприятливе розвивально-виховне освітнє середовище для успішної адаптації студентів першого року навчання через служби психологічної допомоги, до діяльності яких залучено також студентів старших курсів, та інтерактивні навчальні курси, які проходять у форматі семінарів [3].

Спеціально розроблені для студентів першого року навчання курси-семінари $\epsilon$ важливим складником навчально-виховного процесу у вищій школі США. Це пояснюється, по-перше, тим, що студенти, залучаючись до активної діяльності у процесі підготовки до цих семінарів та безпосередньо в ході самих занять, стикаються 3 такими комунікативними моделями, які спрямовані на прагматику письмової й усної комунікацій та формування навичок ефективного спілкування. Крім того, прагматика комунікативних практик дозволяє студентам здобути знання, що забезпечують їхню адаптацію до життя в соціумі в цілому та до освітнього середовища вищого навчального закладу зокрема.

По-друге, комунікативні навички пронизують усі аспекти особистісного розвитку та всі сфери людського життя. Загалом, на переконання І. Енглеберг і Д. Вінн, «комунікація $є$ багатогранною навчальною дисципліною, яка охоплює процеси, методи і продукти людської значущості, виступаючи при цьому її ключовою, визначальною характеристикою» [7, с. 4]. У такий спосіб комунікація слугує підгрунтям для набуття студентами академічного, професійного і соціокультурного досвіду, що в цілому сприяє ефективному формуванню в них гуманітарної культури.

Mema cmammi - висвітлення особливостей змістового наповнення навчальних курсів семінарського типу, спеціально розроблених для студентів першого року навчання на бакалавріаті в США.

У спробі створити стимулююче середовище для розвитку в студентів гуманітарної культури та допомогти їм адаптуватися до академічного середовища вищого навчального закладу, курси-семінари першого року навчання спрямовані на:

- створення динамічної взаємодії між викладачами та студентами, де ідеї і знання передаються й обговорюються в критично-заохочувальній манері, що перетворює студентів на активних учасників власного навчання і виховання;

- підвищення рівня розвитку інтелектуальних навичок студентів, необхідних для аналізу і розв'язання складних питань і проблем у ході подальшого навчання;

- заохочення студентів до виявлення власних прагнень та ресурсів задля розв'язання 
проблем;

- розвиток у студентів стійкої мотивації до здобуття нових знань та набуття трансдисциплінарного досвіду;

- формування адекватної самооцінки та навичок самовиховання;

- розвиток у студентів власного, самостійного стилю академічної та наукової комунікації (усної й письмової), що відрізняється від тієї, до якої вони звикли у старшій школі [5].

У ході контент-аналізу курикулумів із загальної гуманітарної підготовки студентів американських вищих навчальних закладів різного типу встановлено, що тематика курсівсемінарів охоплює обговорення широкого діапазону важливих питань історичного, філософського, соціокультурного аспектів життя людини. Зокрема, в університеті Фурмана студентам першого року навчання пропонуються такі курси-семінари: «Людство, фізика та всесвіт», «Майбутнє енергоносіїв у США», «Математика: історія та сутність», «Роль жінки: між кар'єрою і сім'єю», «Що є нормальною поведінкою?», «Витоки глобальної бідності», «Наркотики, секс та хибний шлях життя», «Університет Фурмана в світі», «Греція та Японія в порівняльному аналізі», «Теорія гри», «В пошуках щастя в США» та ін. [5].

До прикладу, педагогічна спільнота університету Брауна пропонує першокурсникам на вибір понад 100 навчальних курсів семінарського типу, серед яких: «Транснаціональне життя: антропологія міграції та мобільності», «Статистика в усьому», «Підробки! Історія неавтетничних речей», «Ботаніка i сучасна медицина», «Хто володіє минулим?», «Психологія креативності», «Смак безкінечності», «Війни Ізраїлю», «Уведення до художньої прози» та ін. [4].

Зауважмо, що при цьому навчання проходить у малих групах (15-20 студентів). Це дозволяє значно збільшити інтенсивність освітнього процесу та його ефективність, що пришвидшує формування необхідних навичок. За такої ситуації кожний студент отримує зворотній зв'язок про те, як він виконує те чи те завдання, що полегшує засвоєння знань і дозволяє в подальшому ефективно їх застосовувати.

Визначаючи пріоритет забезпечення першокурсників сприятливою атмосферою освітнього середовища, слід у такому контексті ще раз наголосити на комунікації як інтенсивному інструментарії формування у студентів гуманітарної культури.

Реалізація означеного відбувається на двох рівнях:

1) індивідуальному рівні, який передбачає розвиток уміння логічно висловлювати власні думки, слухати інших, ставити питання та аргументовано відповідати на запитання інших;

2) груповому рівні, що грунтується на розвитку вмінь і стратегій колективної взаємодії та публічних виступів, доповідей тощо.

При цьому у практиці вищої школи США часто використовується метод рольової гри, що грунтується на моделюванні заданих ситуацій, вимагаючи від студентів використання певних моделей поведінки та відповідної лексики.

Рольова гра як певна модель спілкування припускає імітування дійсності в ії найбільш істотних рисах: як і в самому житті, вербальна й невербальна поведінка усіх учасників тісно переплітається. Визначальним фактором цього методу є індивідуальний пізнавальний пошук в інтересах групи у процесі підготовки студента до заняття (приміром, підготовка доповіді, робота з різними науковими джерелами у ході підготовки до виконання ролі певної історичної особи та ін.) слугує не лише поглиблення власних знань 3 питання, що досліджується, а й підвищення особистої відповідальності за результативність донесення цих 
знань до інших. Водночас значний виховний ефект містить і колективна оцінка групи щодо виконаної індивідуальної діяльності тим чи тим студентом.

Цікавими, на наш погляд, у переліку курсів-семінарів для студентів першого року навчання у багатьох закладах вищої освіти США (у Гарварді, коледжі Барнарда та ін.) $є$ навчальні курси, що проводяться у формі рольової гри, «Реакція на минуле» та «Подорож у часі». Ці курси дозволяють у найбільш автентичний спосіб «відчути і прожити історію».

Так, у ході курсу «Реакція на минуле» студенти «приміряють» на себе ролі історичних постатей (до початку занять кожному студенту пропонується роль певної історичної особи). Замість того, щоб просто читати про події, вони занурюються в мотивації, перспективи й думки людей, які викарбували історію. Готуючись до занять, студенти читають класичні твори, які допомагають їм осягнути історичний та соціальний контексти життя певних персоналій. Відтворюючи інтелектуальну енергію емоційного переживання, вони самі «проживають» історію певних історичних подій. Виконуючи свої ролі, студенти намагаються спонукати інших учасників до дії стосовно їхнього персонажу та мотивації його вчинків. Приміром, студент може обрати роль китайського науковця XVI століття, який допомагає у вирішенні питання щодо того, хто має стати наступним імператором. Або він може грати роль члена Національної Асамблеї у революційному Парижі 1791р., що намагається створити конституцію посеред панівного хаосу. У такий спосіб вони експериментують, використовуючи свої знання про реальний світ, і водночас розвивають здатність взаємодіяти з іншими людьми [2].

На завершальному етапі гри проводиться ії обговорення. Учасники повинні самі оцінити підсумки гри, власні дії та дії інших учасників, визначити ті проблеми й труднощі, яких вони зазнавали під час гри.

Отже, рольова гра припускає посилення особистісної причетності до всього, що відбувається. Студент «проживає» ситуацію не через власне «Я», а через «Я» відповідної ролі. Це позитивно позначається на результаті, i, як підсумок, сприяє розширенню асоціативної бази у процесі засвоєння навчального матеріалу та має виховне значення. Рольова гра сприяє формуванню навчального співробітництва й партнерства на основі активної взаємодії. Вона також забезпечує розвиток комунікативних навичок та критичного і креативного мислення через аналіз альтернативних способів дій, ідей, запропонованих для виконання завдання гри в ході підведення підсумків.

Своєю чергою, семінари 3 письмової комунікації для першокурсників покликані навчити студентів тому, як писати більш ефективно - логічно й зрозуміло. Для досягнення цієї мети кількість учасників семінару обмежена до дванадцяти студентів. Загалом цільове призначення курсів семінарського типу з письмової комунікації полягає у:

- розвитку у студентів критичного мислення і логічної аргументації через інформаційне письмо та усвідомлення того, що письмо є формою мислення, за допомогою якої різні ідеї набувають письмового вираження;

- ознайомленні 3 проблемою плагіату та інших форм академічної нечесності відповідно до загальної політики вищого навчального закладу;

- оволодінні аналітичними стратегіями та техніками академічного письма;

- розвитку навичок роботи з різними джерелами інформації та здатності синтезувати ідеї з різних джерел із власними думками і досвідом [5].

Потребує також спеціального розгляду проведення курсів-семінарів на основі критичного читання так званих «Величних книг». Концепція «Величних книг» була розроблена в 1909 р. освітянами Гарварду як модель загальної гуманітарної підготовки 
студентів бакалавріату. Згодом, у 1920 р. професор Колумбійського університету Дж. Ерскін першим на теренах США започаткував викладання навчального курсу «Загальні чесноти» (General Honors) за концепцією вивчення класичних творів. Інноваційною для того часу стала його практика проведення семінарів за круглим столом зі студентами з обговорення праць класиків. Означена ініціатива Дж. Ерскіна грунтувалася на його глибокому переконанні в необхідності звернення до західної традиції загальної гуманітарної підготовки студентів, яка охоплювала вивчення творів відомих філософів, літераторів тощо попередніх століть. Зауважимо, що він склав перший список з 60 класичних творів для обов'язкового читання студентами (всі наступні списки зберегли 85 \% позицій, виокремлених Дж. Ерскіним). Знання, здобуті в цій галузі, визначають освічену людину з розвиненою гуманітарною культурою, яка обізнана з працями класичних авторів та здатна працювати над розв'язанням фундаментальних питань людського буття, зокрема етично-моральних [1].

Нині концепція «Величних книг» використовується у вищій школі США як окремий навчальний курс семінарського типу 3 однойменною назвою або як комплексна загальноосвітня підготовка студентів. На переконання Г. Дрейфуса і Ш. Келлі, читання класиків «відроджує» особистісний потенціал людини, відкриваючи його незліченним можливостям вільного вибору в сучасному світі [6].

Так, у коледжі Св. Джона понад 70 років поспіль усі заняття проводяться у формі дискусій на основі прочитаних студентами класичних творів. Загалом лекційна форма занять у цьому закладі вищої школи відсутня: студенти разом 3 викладачами досліджують прочитані твори, тематика яких охоплює майже весь період розвитку західної культури [9]. Адже вивчення й аналіз значущої для західної цивілізації класичної літератури розвиває критичне мислення студентів, збагачує їхній світогляд, виховує їх як гідних громадян своєї країни та світу в цілому, що певним чином сприяє формуванню в них гуманітарної культури. Зрештою, єдиний культурний канон створює загальний простір комунікації, де студенти навчаються працювати над власними відкриттями через обмірковування та дискусію щодо фундаментальних питань існування людства.

Слід відзначити, що цю модель загальної гуманітарної підготовки студентів у США критикують через відсутність уваги до актуальних знань та палкі суперечки з приводу того, які критерії розмежовують західну і незахідну культури, а також ігнорування надбаннями сучасної культурної спадщини.

На противагу комплексній програмі означеної моделі навчальні курси семінарського типу з вивчення творів класичної літератури в курикулумах загальної гуманітарної освіти вищих навчальних закладів у США є доволі розповсюдженими, дозволяючи в навчальновиховному процесі одночасно поєднувати такі задачі, як: продукування соціокультурного знання; виховання студентів як суб'єктів культури; розвиток критичного і креативного мислення, самостійності та неупередженості оцінок і суджень; формування навичок конструктивної взаємодії, що в цілому забезпечує ефективний розвиток у студентів гуманітарної культури.

Отже, окреслене вище дозволяє дійти таких висновків, що навчальні курси-семінари в системі загальної гуманітарної підготовки американських студентів використовують комунікацію як ефективний інструментарій формування у студентів гуманітарної культури та характеризуються: навчанням у малочисельних групах; тісним зв'язком навичок, що формуються, та змістом самих курсів, який передбачає розвиток комунікативних навичок, критичного мислення, рефлексії та міжособистісної взаємодії; роботою 3 автентичними авторськими текстами; інтеграцією знань різного соціокультурного контексту, що 
реалізується шляхом застосування методу кейсів, рольової гри.

\section{Література}

1. Adler M. J. Reforming Education: The Opening of the American Mind / Mortimer Jerome Adler, Geraldine Van Doren. - New York: Collier Books and Macmillan Publishing, 1990. - 362 p. 2. Barnard Education : 2014-15 Catalogue [Electronic resource]. - Mode of access: http://catalog.barnard.edu/barnard-college/curriculum/requirements-liberal-arts-degree/ 3. Best Practices for Teaching First-year Undergraduates [Electronic resource]. - Mode of access : http://www.cmu.edu/ teaching/ resources/PublicationsArchives/InternalReports/BestPractices1stYears.pdf. 4. Brown University First Year Seminars 2014-15[Electronic resource]. - Mode of access : https://www.brown.edu/academics/college/degree/sites/ brown.edu.academics. college.degree/files/uploads/2014-15_FYS.pdf. 5. Building a Foundation for Liberal Learning : First Year Seminars at Furman University 2013-2014 [Electronic resource]. - Mode of access : http://www.furman.edu/academics/fys/Documents/2013-2014_fys.pdf. 6. Dreyfus H. L. All Things Shining : Reading the Western Classics to Find Meaning in a Secular / Hubert L. Dreyfus, Sean Dorrance Kelly. - Free Press, 2011. - 272 p. 7. Engleberg I. N. Think Communication / Isa N. Engleberg, Dianna R. Wynn. - Pearson, 2010. - 400 p. 8. Hyland K. Teaching and Researching Writing / Ken Hyland. - London : Longman, 2002. - 254 p. 9. Rule W. S. Seventy Years of Changing Great Books at St. John's College : Dissertation [Electronic resource] / William Scott Rule. - Georgia State University, 2009. - 166 p. - Mode of access : http://scholarworks.gsu.edu /cgi/ viewcontent.cgi?article=1036\&context=eps_diss 